\title{
High rates of $\mathbf{N}$ fixation in seagrass sediments measured via a direct ${ }^{30} \mathrm{~N}_{2}$ push-pull method
}

\author{
Lillian R. Aoki*, Karen J. McGlathery \\ Department of Environmental Sciences, University of Virginia, Charlottesville, VA 22904, USA
}

ABSTRACT: Highly productive seagrass meadows often occur in oligotrophic waters, and nitrogen (N) fixation may play a role in supporting the $\mathrm{N}$ demand of the meadows. To date, most studies of $\mathrm{N}$ fixation in seagrass sediments have relied on indirect measurements via the acetylene reduction technique. Recent measurements of $\mathrm{N}$ fixation in submerged estuarine sediments using direct methods (e.g. $\mathrm{N}_{2}$ :Ar ratio) in laboratory core incubations have shown higher rates than acetylene reduction measurements. Direct methods have not yet been applied to seagrass sediments in situ. In this study, we used a new in situ ${ }^{30} \mathrm{~N}_{2}$ push-pull method to measure $\mathrm{N}$ fixation rates in seagrass sediments and compared those rates to traditional acetylene reduction slurries. On average, hourly rates of $\mathrm{N}$ fixation measured via the ${ }^{30} \mathrm{~N}_{2}$ push-pull method were more than an order of magnitude greater than the acetylene reduction rates during summer (388 and $7.8 \mu \mathrm{mol} \mathrm{m} \mathrm{m}^{-2} \mathrm{~h}^{-1}$, respectively). These push-pull rates exceeded other published rates of $\mathrm{N}$ fixation in seagrass sediments (measured via acetylene reduction) but were within the range of reported rates for direct measurements of $\mathrm{N}$ fixation in submerged estuarine sediments. These results indicate the need for further investigation of $\mathrm{N}$ fixation rates in seagrass sediments via direct and in situ measurements. In order to fully understand the role of seagrass meadows in coastal $\mathrm{N}$ cycling, it is critical to accurately determine the magnitude of $\mathrm{N}$ fixation that occurs in these highly productive ecosystems.

KEY WORDS: Nitrogen fixation - Seagrass · Zostera marina $\cdot$ Push-pull $\cdot{ }^{30} \mathrm{~N}_{2}$

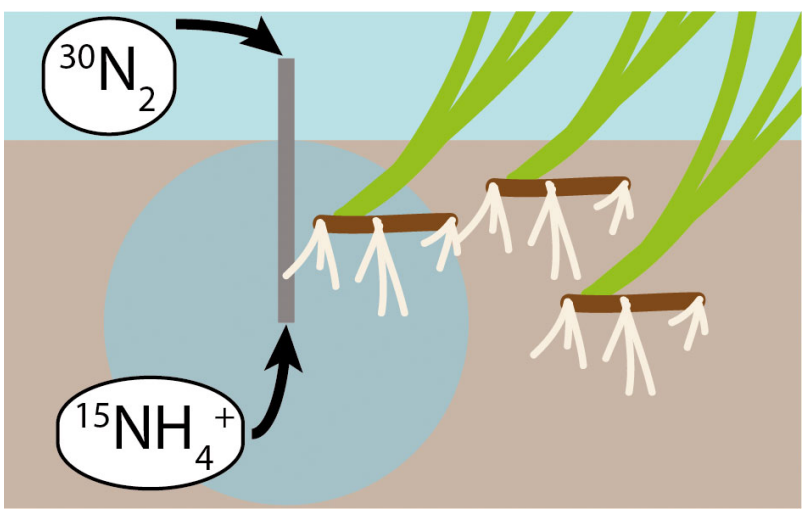

Measuring nitrogen fixation directly (with stable isotopes) and in situ (using a push-pull method) captures the effects of seagrass roots.

Graphic: Lillian Aoki

\section{INTRODUCTION}

Seagrass meadows are highly productive ecosystems that often occur in low-nutrient waters. Nitrogen $(\mathrm{N})$ fixation can be an important source of nutrients, and rates typically exceed those in surrounding benthic habitats (Eyre et al. 2011). Seagrass-associated $\mathrm{N}$ fixation can occur in epiphytes on seagrass leaves and in both surface and sub-surface sediments (McGlathery 2008); a large proportion of $\mathrm{N}$ fixation in seagrass sediments is associated with roots and rhizomes and may be stimulated by plant exudation of fixed carbon (Welsh et al. 1996, McGlathery et al. 1998, Nielsen et al. 2001). Both autotrophic and heterotrophic $\mathrm{N}$ fixers can be important, with sulfatereducing bacteria in particular often accounting for a substantial portion of total $\mathrm{N}$ fixation in seagrass

() The authors 2019. Open Access under Creative Commons by Attribution Licence. Use, distribution and reproduction are unrestricted. Authors and original publication must be credited. 
sediments (Welsh 2000). Understanding the magnitude and drivers of $\mathrm{N}$ fixation in seagrass meadows provides insight into their role as both productivity hotspots and coastal nutrient filters.

A wide range of $\mathrm{N}$ fixation rates are reported in the literature, and rates in temperate meadows are typically lower than in tropical meadows. The majority of studies to date have relied on indirect measurements via acetylene reduction. Because nitrogenase, the enzyme that fixes $\mathrm{N}$, also reduces acetylene to ethylene, sediments can be incubated with acetylene (typically in slurries or cores), and ethylene production is used as a proxy for $\mathrm{N}$ fixation (Capone 1993). The acetylene reduction method is simple and affordable and has been widely adopted in studies of aquatic $\mathrm{N}$ fixation. However, acetylene reduction suffers from numerous drawbacks. Not only is there uncertainty surrounding the conversion ratio of ethylene production to $\mathrm{N}$ fixation (Capone 1988), but the presence of acetylene may alter the microbial community in ways that affect the $\mathrm{N}$ fixation rate (Oremland \& Taylor 1975, Payne 1984, Fulweiler et al. 2015). Sulfatereducing bacteria, among others, may be stimulated or suppressed by the presence of acetylene, and ethylene may be produced or consumed by bacteria during the incubation. The acetylene reduction assay also inhibits $\mathrm{N}$ fixation by design, which can lead to $\mathrm{N}$ limitation and altered $\mathrm{N}$ fixation rates during long incubations (Taylor 1983). Given these drawbacks, there is a clear need for alternative methods to measure $\mathrm{N}$ fixation in coastal sediments.

Recently, several studies have used alternative methods to measure $\mathrm{N}$ fixation in coastal sediments (Gardner et al. 2006, Fulweiler et al. 2007, 2015, Newell et al. 2016). These studies all used direct methods, measuring changes to the dissolved $\mathrm{N}_{2}$ :Ar ratio. In core incubations, changes in the $\mathrm{N}_{2}$ : Ar ratio indicate the net flux of $\mathrm{N}_{2}$ either into or out of sediments; $\mathrm{N}_{2}$ :Ar rates therefore represent the balance of $\mathrm{N}$ fixation (consumes $\mathrm{N}_{2}$ ) and denitrification (produces $\mathrm{N}_{2}$ ). Uptake of $\mathrm{N}_{2}$ into the sediments therefore represents net $\mathrm{N}$ fixation, outweighing denitrification, as measured in some studies (Fulweiler et al. $2007,2015)$. With addition of ${ }^{15} \mathrm{NO}_{3}{ }^{-}$, estimates of denitrification and $\mathrm{N}$ fixation can be determined simultaneously from $\mathrm{N}_{2}$ :Ar fluxes (An et al. 2001), and recent studies have adopted this approach in coastal sediments (Gardner et al. 2006, Newell et al. 2016). In general, these direct $\mathrm{N}_{2}$ :Ar methods estimate higher $\mathrm{N}$ fixation rates than acetylene reduction assays. However, few studies have compared $\mathrm{N}$ fixation measured simultaneously by acetylene reduction and an alternative direct method (Fulweiler et al. 2015). For seagrass ecosystems, there have been no $\mathrm{N}_{2}$ :Ar studies of $\mathrm{N}$ fixation, likely due to the challenges associated with using vegetated cores and the $\mathrm{N}_{2}$ :Ar method. A handful of direct studies of $\mathrm{N}$ fixation have used seagrass cores incubated with ${ }^{30} \mathrm{~N}_{2}$ amendments (O'Donohue et al. 1991, CarlsonPerret et al. 2018). However, no study has investigated $\mathrm{N}$ fixation in seagrass sediments using a direct in situ method.

In this study, we compared $\mathrm{N}$ fixation rates measured with the traditional acetylene reduction assay and a new, in situ direct ${ }^{30} \mathrm{~N}_{2}$ push-pull incubation method. This push-pull method was adapted from a technique that was developed to measure denitrification and dissimilatory nitrate reduction to ammonium in subtidal seagrass sediments (Aoki \& McGlathery 2017). Rather than removing sediment cores to the laboratory for incubation, this technique allows for incubations in sediments with intact shoots after the addition of isotopically labeled $\mathrm{N}$. The natural conditions of flow and light availability are undisturbed, and the measured rates therefore capture variability driven by field conditions and plant effects. Previously, we measured significantly higher rates of denitrification using this technique compared to traditional static core incubations (Aoki \& McGlathery 2017), and we hypothesized that similarly high rates of $\mathrm{N}$ fixation would be measured by applying the push-pull method to ${ }^{30} \mathrm{~N}_{2}$ incubations in seagrass sediments.

\section{MATERIALS AND METHODS}

\subsection{Study site}

This study was conducted in a restored seagrass meadow in South Bay, Virginia, USA, 1 of 4 meadows seeded in a landscape-scale restoration project begun in 2001 (Orth \& McGlathery 2012). Long-term monitoring has shown that the meadow reached a mature steady-state after 9 yr (McGlathery et al. 2012); the current study took place 15-16 yr after seeding. Measurements were made at the original seeded plots of the restoration, i.e. the most mature areas in the interior of the meadow. South Bay is shallow, with a mean water depth of $1.4 \mathrm{~m}$ and a tidal range of $1.2 \mathrm{~m}$ (Fagherazzi \& Wiberg 2009), and water quality is high, with low concentrations of dissolved nutrients and chlorophyll (McGlathery \& Christian 2017).

Measurements of $\mathrm{N}$ fixation rates using acetylene reduction and the new push-pull method were conducted in both seagrass sediments and in experimen- 
tally cleared bare sediments within the meadow. Previous work using acetylene reduction has shown higher rates of $\mathrm{N}$ fixation in seagrass sediments compared to unvegetated sediments (Welsh et al. 1996, Hansen et al. 2000, Cole \& McGlathery 2012), an effect generally attributed to greater availability of organic substrate, especially labile carbon from root exudates, in seagrass sediments (McGlathery 2008). In this study, we compared the rates in seagrass sediments to neighboring cleared sediments that experienced identical environmental conditions in order to isolate the effect of seagrass presence on the $\mathrm{N}$ fixation rates. Small sub-plots $\left(4 \mathrm{~m}^{2}\right)$ were cleared in 2015; seagrass shoots and large rhizomes were removed by hand, and the sub-plots were delineated using plastic lawn edging inserted to a depth of $8 \mathrm{~cm}$ to prevent recolonization by surrounding seagrass ramets. These cleared sub-plots were re-cleared following limited recolonization of seagrass in summer 2016 before the first $\mathrm{N}$ fixation measurements, and were re-cleared again in 2017, before the summer 2017 measurements. Organic matter content (measured using loss on ignition after drying sediments to a constant weight at $60^{\circ} \mathrm{C}$ ) did not vary between the cleared sub-plots and the surrounding seagrass sediments when the plots were first cleared in 2015 or in the following years of the $\mathrm{N}$ fixation measurements (data not shown).

\subsection{Acetylene reduction}

$\mathrm{N}$ fixation rates from sediments and epiphytes were measured using the acetylene reduction technique (Capone 1993) in June (epiphytes only), August, and October 2016, and in April and August 2017. For the sediment incubations, 4 small cores ( $2 \mathrm{~cm}$ inner diameter [ID], $5 \mathrm{~cm}$ depth) were collected haphazardly from each of 3 large (0.4 ha) seagrass plots. Four additional cores were collected haphazardly from the experimentally cleared sub-plot $\left(4 \mathrm{~m}^{2}\right)$ within each seagrass plot. Sediment cores were transported on ice to the laboratory and immediately prepared for incubation. For the epiphyte incubations, 12 seagrass shoots were collected from each of 3 large (0.4 ha) plots during each sampling month. Shoots were held in site water and transported on ice to the laboratory; the shoots were then held overnight on ice in site water bubbled with air and prepared for incubation the following day.

Sediments were transferred to glass vials $(37.5 \mathrm{ml})$ by sub-sampling within the $2 \mathrm{~cm}$ core using a $5 \mathrm{~cm}^{3}$ cut-off plastic syringe. Mass of the sediments was determined and added to the vials with $1 \mathrm{ml}$ of filtered $(0.5 \mu \mathrm{m})$ site water; vials were sealed with silicone septa and aluminum crimp tops. The vials were sparged with argon gas for 5 min to remove oxygen before the addition of $10 \mathrm{ml}$ of acetylene gas, after which the vials were shaken for $10 \mathrm{~s}$ and then vented to atmospheric pressure. Vials were then placed in a temperature-controlled water bath for incubation. A light treatment was used to test for the contribution of autotrophic $\mathrm{N}$ fixation in the sediments; although studies have tended to show the dominance of heterotrophic bacteria as $\mathrm{N}$ fixers in seagrass meadows (e.g. Welsh et al. 1996), a recent study found a strong correlation between cyanobacterial cell counts and $\mathrm{N}$ fixation in seagrass sediments (Russell et al. 2016). A full-spectrum light was used to provide saturating light conditions in the incubation tank, and half of the vials were covered in aluminum foil to provide a dark treatment (except in October 2016 when no light treatment was used and all incubations were dark). After $6 \mathrm{~h}$, the vials were shaken for $30 \mathrm{~s}$ and the headspace was transferred to a pre-evacuated Exetainer using a double-ended needle.

Epiphyte incubations were prepared by selecting at random 6 intact shoots from the 12 shoots collected at each site. The number of leaves on each shoot was recorded, and the upper $15 \mathrm{~cm}$ of leaves 2 and 4 (young and old leaves, respectively) were transferred to $72 \mathrm{ml}$ glass vials filled with $50 \mathrm{ml}$ of filtered $(0.5 \mu \mathrm{m})$ site water. An additional $10 \mathrm{ml}$ of acetylene-saturated filtered site water were added to the vials, and the vials were sealed with septa and aluminum crimps, shaken vigorously for $30 \mathrm{~s}$, and placed in the incubation chamber under the full-spectrum light. Half of the vials were covered with aluminum foil to test the effect of light (except in August and October 2016 when no light treatment was used and all incubations were dark). After $4 \mathrm{~h}$, the vials were removed, shaken for $30 \mathrm{~s}$, and the headspace was transferred to preevacuated Exetainers using a double-ended needle.

Gas samples from all incubations were analyzed on a Shimadzu GC-14A at the Smithsonian Environmental Research Center in Edgewater, MD, USA, within $3 \mathrm{wk}$ of the incubation. The analysis was conducted using a $1.83 \mathrm{~m} \times 0.32 \mathrm{~cm} \times 0.22 \mathrm{~cm}$ column filled with Poropak N 80/100 connected to the flame ionization detector. Ethylene production rates were converted to $\mathrm{N}$ fixation rates using the theoretical 3:1 molar ratio of ethylene to $\mathrm{N}$ (Seitzinger \& Garber 1987). For sediments, $\mathrm{N}$ fixation rates were converted to areal rates using the wet weight, volume, and depth of the sediment core. For the epiphyte rates, the average of leaves 2 and 4 was scaled up to an 
areal rate based on the number of leaves shoot ${ }^{-1}$ and the shoots $\mathrm{m}^{-2}$; shoot densities were measured in 10 replicate $0.25 \mathrm{~m}^{2}$ quadrats at each plot in the meadow during each season.

\section{3. ${ }^{30} \mathrm{~N}_{2}$ push-pull}

We used a ${ }^{30} \mathrm{~N}_{2}$ push-pull method to measure $\mathrm{N}$ fixation directly in the same seagrass and bare plots where sediments were collected for acetylene incubations in summer 2017. Four replicate push-pull incubations were conducted simultaneously, with 2 incubations in bare sediments and 2 incubations in seagrass sediments; 8 total push-pull incubations were conducted over 2 deployments. All deployments occurred under natural daylight conditions. Details of this push-pull method, as developed to measure denitrification, are available elsewhere (Aoki \& McGlathery 2017). The general method and adaptations to measure $\mathrm{N}$ fixation are summarized here.

For each ${ }^{30} \mathrm{~N}_{2}$ push-pull incubation, a mini-piezometer (1.8 $\mathrm{mm}$ ID) was inserted into the sediment to a depth of $5 \mathrm{~cm}$. The piezometer was connected via Viton tubing to a graduated cylinder that served as a reservoir. Approximately $220 \mathrm{ml}$ of porewater were extracted from the sediment using a peristaltic pump at a rate of $4 \mathrm{ml} \mathrm{min}^{-1}$; a layer of castor oil in the graduated cylinder served as a barrier to atmospheric exchange during the pumping processes. Duplicate background samples of the porewater were collected in $12 \mathrm{ml}$ Exetainers (overfilled by $3 \mathrm{ml}$ to prevent atmospheric exchange) and fixed with $50 \mu \mathrm{l}$ of saturated $\mathrm{ZnCl}_{2}$. These background samples were stored underwater until analysis using membrane inlet mass spectrometry (MIMS) within $4 \mathrm{wk}$.

Approximately $20 \mathrm{ml}$ of artificial seawater saturated with ${ }^{30} \mathrm{~N}_{2}$ gas were then added to the reservoir. The ${ }^{30} \mathrm{~N}_{2}$-saturated seawater was prepared in the laboratory by first bubbling artificial seawater with Ar gas to strip ambient $\mathrm{N}_{2}$ and $\mathrm{O}_{2}$, transferring the seawater to a gas-tight Tedlar bag, adding ${ }^{30} \mathrm{~N}_{2}$ (Cambridge Isotope Laboratory, 98\% purity), and shaking overnight. The ${ }^{30} \mathrm{~N}_{2}$-seawater was transported to the field in gas-tight glass vials stored underwater. Immediately after the addition of the ${ }^{30} \mathrm{~N}_{2}$-seawater to the reservoir, a second set of samples was collected in Exetainers and fixed with $\mathrm{ZnCl}_{2}$. These samples marked the beginning of the incubation (Time 0) and were also stored underwater until analysis via MIMS within $4 \mathrm{wk}$. The isotopically labeled porewater was then pumped back into the sediment and allowed to incubate in situ for $2 \mathrm{~h}$. The total volume of amended porewater influenced sediments to a depth of $10 \mathrm{~cm}$ below the surface $(5 \mathrm{~cm}$ below the tip of the piezometer). At the end of the incubation, a small sediment core was collected at the injection site $(2.5 \mathrm{~cm}$ ID, $10 \mathrm{~cm}$ depth) and frozen until analysis.

\subsection{Sample analysis and calculations}

The ${ }^{30} \mathrm{~N}_{2}$ push-pull samples were analyzed with a paired vial approach, summarized in Fig. 1. Of the duplicate background porewater samples, 1 duplicate was analyzed via MIMS without modification, and the second duplicate was first oxidized with hypobromite (prepared as per Yin et al. 2014) and then analyzed via MIMS. The hypobromite converts any $\mathrm{NH}_{4}{ }^{+}$in the sample to $\mathrm{N}_{2}$ i the oxidation of ${ }^{15} \mathrm{NH}_{4}{ }^{+}$ increases the concentrations of ${ }^{29} \mathrm{~N}_{2}$ and ${ }^{30} \mathrm{~N}_{2}$ compared to the unoxidized sample. The difference in concentration of ${ }^{29} \mathrm{~N}_{2}$ and ${ }^{30} \mathrm{~N}_{2}$ in the oxidized vial compared to the untreated vial therefore corresponds to the concentration of ${ }^{15} \mathrm{NH}_{4}{ }^{+}$in the sample, i.e. $\left[{ }^{15} \mathrm{NH}_{4}{ }^{+}\right]=2 \times \Delta\left[{ }^{30} \mathrm{~N}_{2}\right]+\Delta\left[{ }^{29} \mathrm{~N}_{2}\right]$. Using the paired background vials, we calculated the background

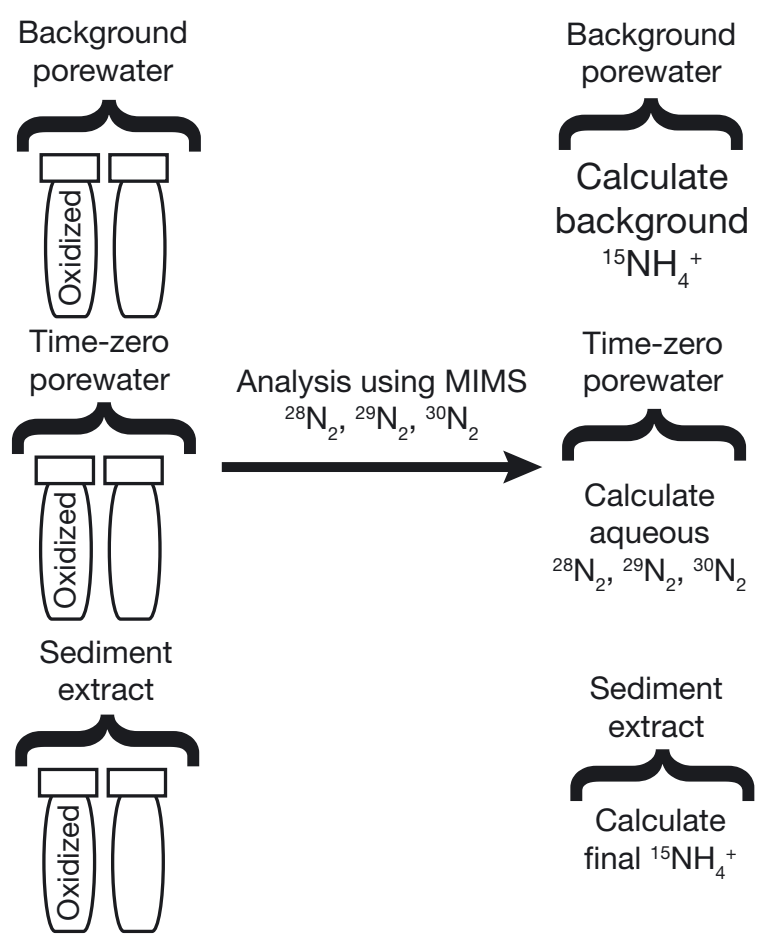

Fig. 1. Paired vial approach for the membrane inlet mass spectrometry (MIMS) analysis. One duplicate vial was oxidized with hypobromite to convert $\mathrm{NH}_{4}{ }^{+}$to $\mathrm{N}_{2}$ i the amount of $\mathrm{NH}_{4}{ }^{+}$in the background samples and sediment extract was then determined by comparing the concentrations of $\mathrm{N}_{2}$ in the oxidized and unoxidized vials. Aqueous concentrations of $\mathrm{N}_{2}$ were determined from the Time 0 porewater samples 
concentrations of ${ }^{29} \mathrm{~N}_{2}$, ${ }^{30} \mathrm{~N}_{2}$, and ${ }^{15} \mathrm{NH}_{4}{ }^{+}$. We then analyzed the Time 0 vials (the samples collected immediately after addition of the isotope label) in order to determine $\left[{ }^{29} \mathrm{~N}_{2}\right]_{\text {aqueous }}$ and $\left[{ }^{30} \mathrm{~N}_{2}\right]_{\text {aqueous }}$ i.e. the concentrations of ${ }^{29} \mathrm{~N}_{2}$ and ${ }^{30} \mathrm{~N}_{2}$ present in the porewater after the addition of the isotope label.

In order to determine the amount of ${ }^{15} \mathrm{NH}_{4}{ }^{+}$produced during the incubation, we again used a paired vial approach with the sediment samples collected at the end of the incubation. The frozen sediment cores were defrosted and shaken for $1 \mathrm{~h}$ with $90 \mathrm{ml}$ of $2 \mathrm{M}$ $\mathrm{KCl}$ to extract ammonium. The sediments were then centrifuged, and the supernatant of each core was filtered $(0.45 \mu \mathrm{m})$ and transferred to a set of 3 Exetainers. One vial was analyzed via MIMS without modification, and the remaining 2 vials were oxidized with hypobromite and then analyzed. Again, the difference in concentration of ${ }^{29} \mathrm{~N}_{2}$ and ${ }^{30} \mathrm{~N}_{2}$ in the oxidized vials compared to the untreated vial corresponded to the amount of ${ }^{15} \mathrm{NH}_{4}{ }^{+}$present in the sediments and porewater at the end of the incubation. We subtracted the background concentration of ${ }^{15} \mathrm{NH}_{4}{ }^{+}$(determined from the paired background vials) in order to calculate $\left[{ }^{15} \mathrm{NH}_{4}{ }^{+}\right]_{\text {produced, }}$ i.e. the total $\left[{ }^{15} \mathrm{NH}_{4}{ }^{+}\right]$produced during the incubation.

The $\left[{ }^{15} \mathrm{NH}_{4}{ }^{+}\right]_{\text {produced }}$ was assumed to derive from fixation of both the added ${ }^{30} \mathrm{~N}_{2}$ gas and naturally present ${ }^{29} \mathrm{~N}_{2}$. We used the calculated values of $\left[{ }^{15} \mathrm{NH}_{4}{ }^{+}\right]_{\text {fixed, }}\left[{ }^{29} \mathrm{~N}_{2}\right]_{\text {aqueous }}$ and $\left[{ }^{30} \mathrm{~N}_{2}\right]_{\text {aqueous }}$ in the following equations to determine $\left[{ }^{29} \mathrm{~N}_{2}\right]_{\text {fixed }}$ and $\left[{ }^{30} \mathrm{~N}_{2}\right]_{\text {fixed }}$, i.e. the concentrations of ${ }^{29} \mathrm{~N}_{2}$ and ${ }^{30} \mathrm{~N}_{2}$ that underwent fixation during the incubation:

$\left[{ }^{15} \mathrm{NH}_{4}\right]_{\text {produced }}=2 \times\left[{ }^{30} \mathrm{~N}_{2}\right]_{\text {fixed }}+\left[{ }^{29} \mathrm{~N}_{2}\right]_{\text {fixed }}$

$\left[{ }^{30} \mathrm{~N}_{2}\right]_{\text {fixed }} /\left[{ }^{29} \mathrm{~N}_{2}\right]_{\text {fixed }}=\left[{ }^{30} \mathrm{~N}_{2}\right]_{\text {aqueous }} /\left[{ }^{29} \mathrm{~N}_{2}\right]_{\text {aqueous }}$

Eq. (1) assumes that the ${ }^{15} \mathrm{NH}_{4}{ }^{+}$present in the sediment extract is derived from fixation of either ${ }^{29} \mathrm{~N}_{2}$ or ${ }^{30} \mathrm{~N}_{2}$. Eq. (2) assumes that the ${ }^{30} \mathrm{~N}_{2}$ and ${ }^{29} \mathrm{~N}_{2}$ are well mixed in the porewater and are fixed randomly; therefore, the relative amount of each species that is fixed corresponds to the relative concentration of that species in the porewater. The 2 equations could therefore be solved for the 2 unknowns, $\left[{ }^{30} \mathrm{~N}_{2}\right]_{\text {fixed }}$ and $\left[{ }^{29} \mathrm{~N}_{2}\right]_{\text {fixed }}$, i.e. the concentrations of ${ }^{29} \mathrm{~N}_{2}$ and ${ }^{30} \mathrm{~N}_{2}$ that underwent fixation during the incubation.

In addition to $\left[{ }^{29} \mathrm{~N}_{2}\right]_{\text {fixed }}$ and $\left[{ }^{30} \mathrm{~N}_{2}\right]_{\text {fixed }}$, a significant proportion of the $\mathrm{N}$ that underwent fixation was expected to be ${ }^{28} \mathrm{~N}_{2}$. Our measurements showed that after adding the ${ }^{30} \mathrm{~N}_{2}$ label to the porewater, the concentration of ${ }^{30} \mathrm{~N}_{2}$ increased $>100 \times$ compared to the background levels, from approximately 0.02 to $4 \mu \mathrm{M}$. This concentration was sufficient to support measureable production of ${ }^{15} \mathrm{NH}_{4}$; however, only a small portion of the $\mathrm{N}_{2}$ pool was labeled. By contrast, the concentration of ${ }^{28} \mathrm{~N}_{2}$ in the porewater was around $380 \mu \mathrm{M}$. Therefore, we used Eq. (3) to calculate the total concentration of $\mathrm{N}_{2}$ that underwent fixation during the incubation, again based on the assumption that all species of $\mathrm{N}_{2}$ were well mixed in the porewater, and thus the relative amount of ${ }^{30} \mathrm{~N}_{2}$ that was fixed corresponds to the relative concentration of ${ }^{30} \mathrm{~N}_{2}$ in the porewater:

$\left[{ }^{30} \mathrm{~N}_{2}\right]_{\text {fixed }} /\left[{ }^{\text {total }} \mathrm{N}_{2}\right]_{\text {fixed }}=\left[{ }^{30} \mathrm{~N}_{2}\right]_{\text {aqueous }} /\left[{ }^{\text {total }} \mathrm{N}_{2}\right]_{\text {aqueous }}$

Having calculated [ $\left.{ }^{\text {total }} \mathrm{N}_{2}\right]_{\text {fixed, }}$ the total concentration of $\mathrm{N}_{2}$ that underwent fixation during the incubation, we used the depth of the sediment core and the porosity of the sediment to determine the volume of porewater in the core and therefore the total amount of $\mathrm{N}_{\text {2fixed }}$. Using the duration of the incubation, we calculated the $\mathrm{N}$ fixation rate in $\mu \mathrm{mol} \mathrm{N}_{2} \mathrm{~cm}^{-3}$ sediment $\mathrm{h}^{-1}$. By integrating over the depth of the sediment core, we converted the rate into an areal $\mathrm{N}$ fixation rate.

\subsection{Statistical analysis}

For the acetylene reduction incubations, individual sediment and leaf incubations were pooled to produce plot-level averages ( $\mathrm{n}=3$ replicate plots). All analyses were conducted in R 3.3.3 (R Core Team 2018). The effects of the light treatment, seagrass presence, and season on $\mathrm{N}$ fixation rates were tested using repeated-measures ANOVA using the 'nlme' and 'car' packages (Fox \& Weisberg 2011, Pinheiro et al. 2018). Normality and homoscedasticity of residuals were assessed graphically; data did not require transformation to meet assumptions. Post hoc contrasts were performed for significant effects using the 'phia' package (De Rosario-Martinez 2015). The effect of seagrass presence on the push-pull rates was determined using a $t$-test; push-pull and acetylene reduction rates were also compared using a $t$-test.

\section{RESULTS}

\subsection{Acetylene reduction}

Hourly $\mathrm{N}$ fixation rates measured from acetylene reduction in the sediments peaked in August and were low in April and October, ranging from 0 to $18.8 \mu \mathrm{mol} \mathrm{N} \mathrm{N}_{2} \mathrm{~m}^{-2} \mathrm{~h}^{-1}$ across all seasons (Fig. 2). The repeated measures ANOVA showed a significant seasonal effect $\left(F_{3,24}=6.135, \mathrm{p}=0.003\right)$ as well as 

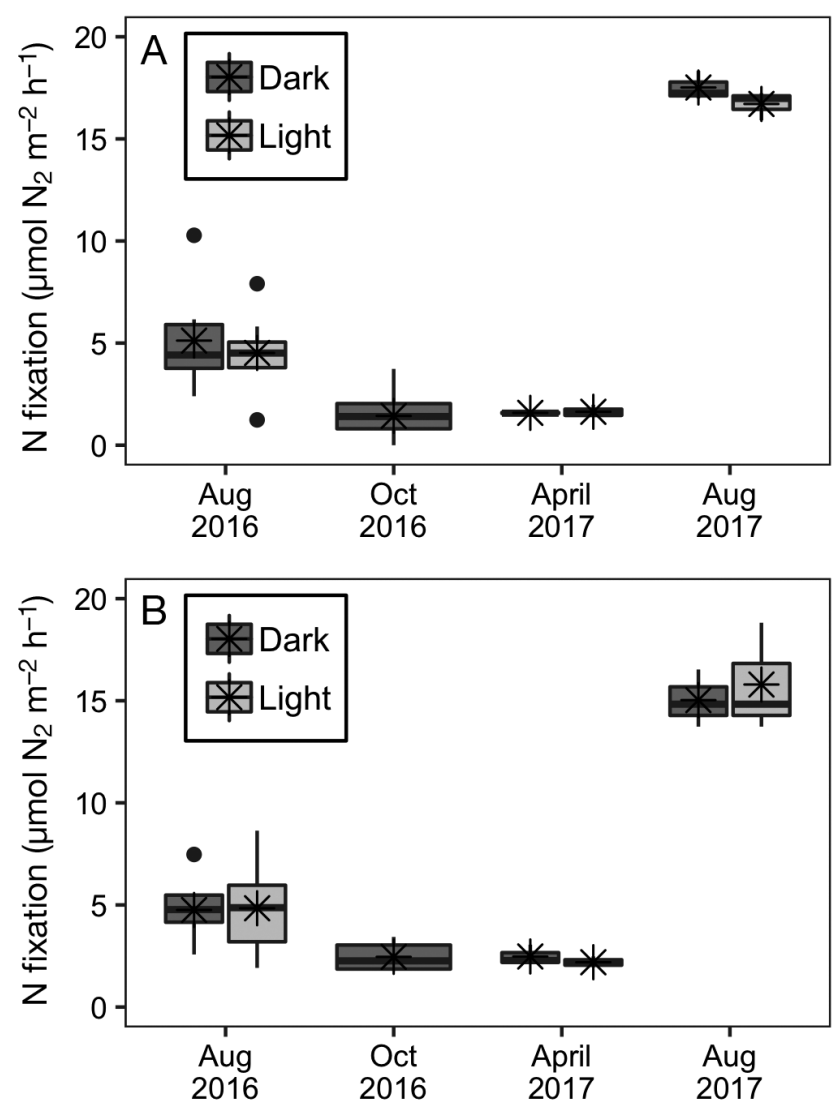

Fig. 2. $\mathrm{N}$ fixation rates measured via acetylene reduction. Rates were comparable in (A) bare sediments and (B) seagrass sediments, showed no significant effect of light, and peaked in summer. The box-and-whisker plots show the $25^{\text {th }}$ to $75^{\text {th }}$ quartiles in the box, with black bars at the median and stars at the mean rates. The whiskers denote maximum and minimum rates up to $1.5 \times$ the length of the box; outlier rates are shown individually as black dots

a significant interaction between season and seagrass presence $\left(F_{3,24}=3.909, p=0.02\right)$. However, the main effects of light and seagrass presence were not significant. Limited light penetration into the sediment slurry and the absence of any fully intact plants in the slurries likely restricted the effects of these treatments. Post hoc contrasts showed that the N fixation rates were significantly greater in both summers compared to the spring and fall rates, and in summer 2017, the bare rates were significantly greater than the seagrass rates.

Hourly $\mathrm{N}$ fixation rates measured from acetylene reduction in the leaf incubations were generally low, between 0 and $16.9 \mu \mathrm{mol} \mathrm{N} \mathrm{N}_{2}^{-2} \mathrm{~h}^{-1}$. Rates were undetectable in April and October and peaked in August, when the seagrass blades were more heavily colonized by epiphytes (Fig. 3). Overall, there was no significant effect of light across the 3 mo of light treatment (repeated measures ANOVA, $F_{1,10}=0.78$,

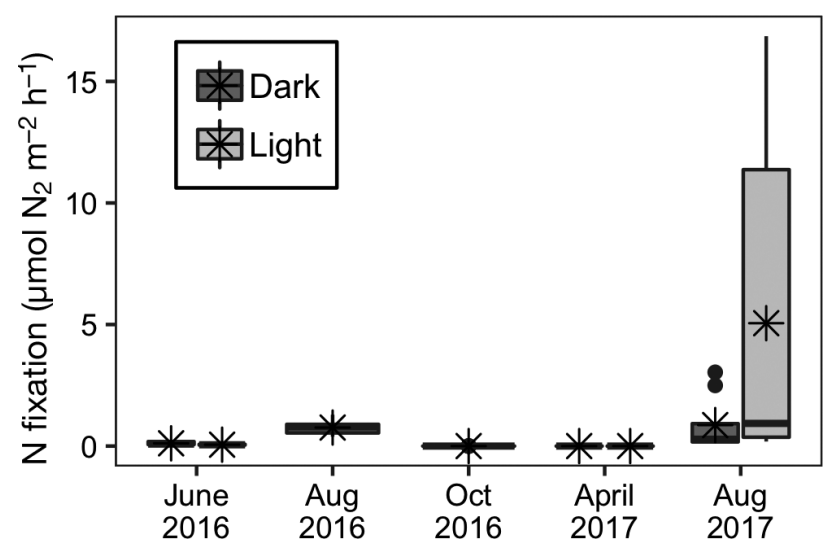

Fig. 3. N fixation rates measured via acetylene reduction on seagrass epiphytes. Rates were low and showed no significant effect of light, although peak rates in the light in August 2017 suggested the presence of autotrophic $\mathrm{N}$ fixers. Box plot parameters as in Fig. 2

$\mathrm{p}=0.39$ ), indicating the dominance of heterotrophic $\mathrm{N}$ fixers. However, in August 2017, individual leaves incubated in the light showed rates up to $10 \times$ higher than the leaves incubated in the dark, indicating the presence of autotrophic $\mathrm{N}$ fixers.

\section{2. ${ }^{30} \mathrm{~N}_{2}$ push-pull}

Hourly $\mathrm{N}$ fixation rates calculated from the ${ }^{30} \mathrm{~N}_{2}$ push-pull incubations exceeded the acetylene reduction rates by an order of magnitude ( $t$-test, p < 0.0005). There was a trend of higher ${ }^{30} \mathrm{~N}_{2}$ push-pull rates in seagrass compared to bare sediments (388 vs. $268 \mu \mathrm{mol} \mathrm{N} \mathrm{N}_{2} \mathrm{~m}^{-2} \mathrm{~h}^{-1}$ respectively, Fig. 4), although

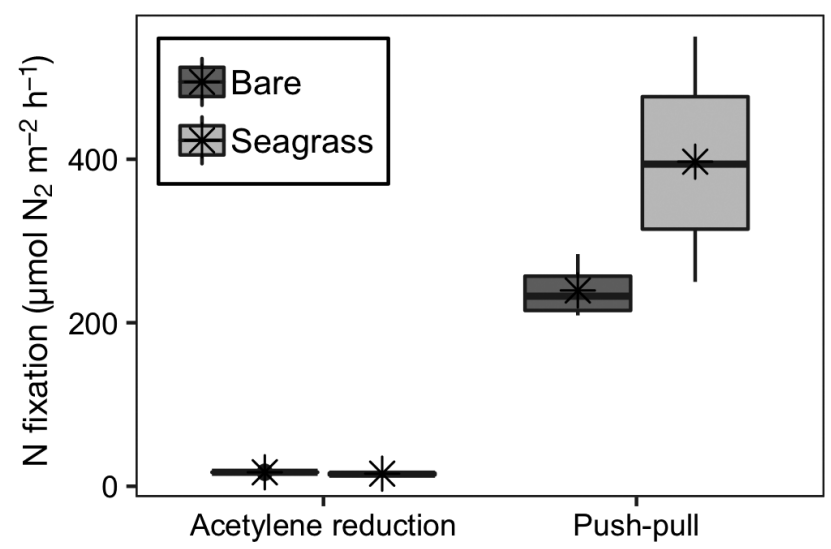

Fig. 4. $\mathrm{N}$ fixation rates measured via the ${ }^{30} \mathrm{~N}_{2}$ push-pull method. Rates were significantly greater than rates measured using acetylene reduction in summer 2017; the ${ }^{30} \mathrm{~N}_{2}$ push-pull rates were highly variable and showed a pattern of higher rates in seagrass sediments compared to bare sediments. Box plot parameters as in Fig. 2 
seagrass and bare rates were not significantly different due to high variation and limited replication ( $t$-test, $\mathrm{p}=0.18 ; \mathrm{n}=4)$. Our previous work on denitrification in these sediments showed hot spots of microbial activity in the seagrass rhizosphere driven by spatially and temporally variable plant effects (Aoki \& McGlathery 2018). We hypothesize that similarly variable plant effects contributed to the wide range of $\mathrm{N}$ fixation rates measured via the push-pull method.

\section{DISCUSSION}

\subsection{Push-pull vs. acetylene reduction rates}

The main finding from this study was that much higher and more variable $\mathrm{N}$ fixation rates were measured using the direct, in situ push-pull method compared to traditional acetylene reduction slurries. The areal $\mathrm{N}$ fixation rates calculated from the acetylene reduction slurries $\left(2-19 \mu \mathrm{mol} \mathrm{N} \mathrm{N}_{2} \mathrm{~m}^{-2} \mathrm{~h}^{-1}\right)$ showed good agreement with previous studies using acetylene reduction (Table 1). However, the areal rates calculated from the ${ }^{30} \mathrm{~N}_{2}$ push-pull incubations were substantially higher than rates measured via acetylene reduction (250-550 $\mu \mathrm{mol} \mathrm{N} \mathrm{N}^{-2} \mathrm{~h}^{-1}$ ), and these high rates are likely indicative of hotspots of microbial activity associated with seagrass root activity. Acetylene is known to alter the microbial community, and in particular can alter the abundance of species of sulfur and sulfate-reducing bacteria over short time scales (Fulweiler et al. 2015). Although we did not assess the role of sulfate-reducing bacteria in this study, previous work has clearly shown the importance of these microbes as heterotrophic $\mathrm{N}$ fixers in marine environments, including seagrass sediments (e.g. Welsh et al. 1996, McGlathery et al. 1998). More recent studies that use direct methods (e.g. $\mathrm{N}_{2}$ : $\mathrm{Ar}$ ratio) have also found rates that exceed the acetylene reduction rates and include values similar to the ${ }^{30} \mathrm{~N}_{2}$ push-pull results reported here (Table 1). Our direct in situ measurements suggest that $\mathrm{N}$ fixation in seagrass sediments may be as much as an order of magnitude greater than assumed previously based on traditional acetylene reduction methods.

It is important to emphasize the 2 distinct ways in which the ${ }^{30} \mathrm{~N}_{2}$ push-pull method differs from the slurry incubations. First, the use of ${ }^{30} \mathrm{~N}_{2}$ rather than acetylene reduction provides a direct measurement of $\mathrm{N}$ fixation and avoids the artifacts associated with acetylene addition on the microbial community. Second, because the push-pull method is conducted in situ, it captures the natural plant effects on $\mathrm{N}$ fixation. Photosynthetic activity in seagrass sediments can drive $\mathrm{N}$ fixation in subsurface sediments through the exudation of labile organic compounds (Welsh et al. 1996, McGlathery et al. 1998). By keeping the seagrass shoots and the heterogeneous sediment matrix intact, and by not interrupting the environmental drivers of plant metabolism (especially light availability and flow), the push-pull method captures the full plant effect on $\mathrm{N}$ fixation rates, including the natural variability in the plant effects. The greater mag-

Table 1. Summary of studies measuring nitrogen $(\mathrm{N})$ fixation rates by different methods. $\mathrm{N}$ fixation rates measured with acetylene reduction are typically lower than rates measured with direct techniques

\begin{tabular}{|c|c|c|c|}
\hline $\begin{array}{l}\mathrm{N} \text { fixation rate } \\
\left(\mu \mathrm{mol} \mathrm{N}_{2} \mathrm{~m}^{-2} \mathrm{~h}^{-1}\right)\end{array}$ & Species; season; site & Method & Citation \\
\hline $6-22$ & $\begin{array}{l}\text { Zostera noltii; summer; Arcachon Bay, } \\
\text { France }\end{array}$ & $\begin{array}{l}\text { Acetylene reduction, added } \\
\text { to headspace of cores }\end{array}$ & Welsh et al. (1996) \\
\hline $4-20$ & Z. marina; summer; Limfjord, Denmark & $\begin{array}{l}\text { Acetylene reduction, added } \\
\text { to porewater of cores via } \\
\text { perfusion }\end{array}$ & McGlathery et al. (1998) \\
\hline $3-90$ & $\begin{array}{l}\text { Z. mulleri, Z. nigicalaous; spring and } \\
\text { summer; Port Philip Bay, Australia }\end{array}$ & $\begin{array}{l}\text { Acetylene reduction, injected } \\
\text { into core sediments }\end{array}$ & Cook et al. (2015) \\
\hline $0-97$ & $\begin{array}{l}\text { Unvegetated sediment; all seasons; } \\
\text { Texas estuaries }\end{array}$ & $\begin{array}{l}\mathrm{N}_{2} \text { :Ar cores, with }{ }^{15} \mathrm{NO}_{3} \\
\text { addition }\end{array}$ & Gardner et al. (2006) \\
\hline $25-650$ & $\begin{array}{l}\text { Unvegetated sediment; summer; } \\
\text { Narragansett Bay, Rhode Island (RI) }\end{array}$ & $\mathrm{N}_{2}$ :Ar cores & Fulweiler et al. (2007) \\
\hline $49-103$ & $\begin{array}{l}\text { Unvegetated sediment; fall; Waquoit Bay, } \\
\text { RI }\end{array}$ & $\begin{array}{l}\mathrm{N}_{2}: \text { Ar cores, with }{ }^{15} \mathrm{NO}_{3} \text { and } \\
{ }^{30} \mathrm{~N}_{2} \text { additions }\end{array}$ & Newell et al. (2016) \\
\hline $250-550$ & $\begin{array}{l}\text { Z. marina; summer; South Bay, Virginia } \\
\text { (VA) }\end{array}$ & ${ }^{30} \mathrm{~N}_{2}$ push-pull & This study \\
\hline $2-19$ & $Z$ marina; summer; South Bay, VA & $\begin{array}{l}\text { Acetylene reduction, sediment } \\
\text { slurries }\end{array}$ & This study \\
\hline
\end{tabular}


nitude of the ${ }^{30} \mathrm{~N}_{2}$ push-pull rates, as well as the large range of rates, is therefore due to both the direct measurement and the in situ aspects of the pushpull approach. Disentangling how much the direct measurement versus the in situ aspects contribute to the magnitude of the push-pull rates would require a comparison between cores incubated with ${ }^{30} \mathrm{~N}_{2}$ amendments and push-pull incubations. We unfortunately did not perform this comparison. A recent study did use cores incubated with ${ }^{30} \mathrm{~N}_{2}$ to study $\mathrm{N}$ fixation in subtropical Zostera muelleri meadows and found rates comparable to literature rates measured using acetylene reduction (Carlson-Perret et al. 2018). This finding would suggest that the in situ aspects of the push-pull method are of primary importance. However, a direct comparison between ${ }^{30} \mathrm{~N}_{2}$ cores and push-pull measurements at the same site is needed to fully answer this question.

In comparing the push-pull and acetylene reduction rates measured here, 2 experimental differences are worth highlighting. First, due to practical considerations, the push-pull incubations were limited to $2 \mathrm{~h}$ and could not be maintained for the same duration as the acetylene reduction incubations $(6 \mathrm{~h})$. Previous studies have found consistently linear rates for acetylene reduction over $6 \mathrm{~h}$ incubations (O'Donohue et al. 1991); however, the difference in the duration of the 2 methods complicates direct comparison. Similarly, in the push-pull incubations, the sediment was amended to a depth of $\sim 10 \mathrm{~cm}$ below the surface, whereas the slurry incubations included a depth only to $5 \mathrm{~cm}$ below the surface. In this system, the majority $(>90 \%)$ of belowground seagrass biomass occurs above $5 \mathrm{~cm}$ (K. McGlathery unpubl. data); considering only depth, the slurry incubations might therefore be biased to higher rates compared to the pushpull rates. However, given how much greater the push-pull rates were, this source of bias appears unimportant compared to other differences in the 2 techniques.

\subsection{Methodological considerations for the push-pull method}

The push-pull method shows promise for capturing in situ plant effects on $\mathrm{N}$ fixation; however, there are a number of limitations to the method and ways in which it could be improved in future implementations. One consideration is that the incubations are open, so there would be loss of the ${ }^{30} \mathrm{~N}_{2}$ amendment and potentially of the ${ }^{15} \mathrm{NH}_{4}{ }^{+}$produced during the incubation as well. This loss could potentially be addressed through the addition of a conservative gas tracer, such as $\mathrm{Ar}$, to the amended porewater. However, in the protocol used here, the final step of the calculations was to estimate the total amount of $\mathrm{N}_{2}$ fixed, including ${ }^{28} \mathrm{~N}_{2},{ }^{29} \mathrm{~N}_{2}$, and ${ }^{30} \mathrm{~N}_{2}$, based on the ratios of these dissolved isotopologues immediately after the ${ }^{30} \mathrm{~N}_{2}$ addition. The vast majority ( $>98 \%$ ) of $\mathrm{N}_{2}$ dissolved in the porewater remained ${ }^{28} \mathrm{~N}_{2}$, even after the ${ }^{30} \mathrm{~N}_{2}$ addition. Therefore, the loss of some portion of the ${ }^{30} \mathrm{~N}_{2}$ addition would have a relatively small impact on the calculation of the total $\mathrm{N}_{2}$ fixed, as described in Eq. (3).

A potentially larger loss of ${ }^{15} \mathrm{NH}_{4}{ }^{+}$may occur through the uptake of $\mathrm{NH}_{4}{ }^{+}$into bacterial or seagrass biomass over the course of the incubation. Measured rates of $\mathrm{NH}_{4}{ }^{+}$uptake by roots of $Z$. marina vary by orders of magnitude (see McGlathery 2008 and references therein); however, studies of other Zostera species using ${ }^{30} \mathrm{~N}_{2}$-amendments have shown the accumulation of ${ }^{15} \mathrm{~N}$ in seagrass tissue within $5-6 \mathrm{~h}$ (O'Donohue et al. 1991, Carlson-Perret et al. 2018). It is therefore reasonable to expect that some portion of the ${ }^{15} \mathrm{NH}_{4}{ }^{+}$fixed in the sediments will transfer to the seagrass during a $2 \mathrm{~h}$ incubation. To address this factor, any future implementation of the push-pull method ought to include collection of seagrass tissue for analysis for ${ }^{15} \mathrm{~N}$ uptake.

A third methodological consideration is that the background level of exchangeable ${ }^{15} \mathrm{NH}_{4}{ }^{+}$present in the sediments could interfere with the calculations. Here, we compared the final amount of ${ }^{15} \mathrm{NH}_{4}{ }^{+}$measured by $\mathrm{KCl}$ extraction of the sediments collected at the end of the incubation with the initial concentration of ${ }^{15} \mathrm{NH}_{4}{ }^{+}$dissolved in the porewater. Depending on the sediment type and background $\mathrm{NH}_{4}{ }^{+}$concentrations, this approach could include large amounts of background ${ }^{15} \mathrm{NH}_{4}{ }^{+}$that would lead to overestimation of $\mathrm{N}$ fixation. Sediments with high clay content have higher concentrations of exchangeable $\mathrm{NH}_{4}{ }^{+}$, due to adsorption and limited porewater exchange (Mackin \& Aller 1984); high organic matter content also increases $\mathrm{NH}_{4}{ }^{+}$concentrations through remineralization. In our study, we collected end-ofincubation porewater samples immediately before collecting the sediment samples, and these porewater samples had similar concentrations of ${ }^{15} \mathrm{NH}_{4}{ }^{+}$to the sediment extracts, likely due to the low organic matter content $(<2.5 \%)$ and sandy sediments with minimal clay content at this site (McGlathery 2016). To prevent overestimation from background ${ }^{15} \mathrm{NH}_{4}{ }^{+}$ in future incubations, a simple strategy would be to collect a pre-incubation sediment sample for $\mathrm{KCl}$ extraction. Seagrass sediments are highly heteroge- 
neous, and it would be important to collect sufficient samples to characterize the spatial variability in extractable $\mathrm{NH}_{4}{ }^{+}$.

\subsection{Seagrass effect on $\mathbf{N}$ fixation}

We relied on the acetylene reduction leaf and slurry incubations to assess the contribution of epiphyte-associated $\mathrm{N}$ fixation and the importance of heterotrophic versus autotrophic $\mathrm{N}$ fixation (measured by the light treatment). A strong light effect was not expected in the sediment slurries since light is rapidly attenuated below depths of $\sim 1 \mathrm{~mm}$ in sandy sediments (Cartaxana et al. 2016), thus limiting the habitat for autotrophic bacteria. We found no significant light effect in either the sediment slurry or leaf incubations, confirming earlier findings from this site that heterotrophic bacteria dominate $\mathrm{N}$ fixation in both sediments and epiphytes (Cole \& McGlathery 2012). The contribution from epiphytes to the total $N$ fixation rate was low, about $20 \%$ of total $\mathrm{N}$ fixation during summer and undetectable in spring and fall. Thus, heterotrophic $\mathrm{N}$ fixation in the sediments was the dominant source of $\mathrm{N}$ fixation throughout the year.

Heterotrophic $\mathrm{N}$ fixation is commonly observed in seagrass meadow sediments and is likely stimulated by the release of photosynthetic exudates by plant roots (Welsh et al. 1996, McGlathery et al. 1998, Hansen et al. 2000). However, we found no significant effect in the acetylene incubations of seagrass cover on $\mathrm{N}$ fixation rates. This result likely comes from the similar conditions in the vegetated and unvegetated sediments used in this study. Unlike in previous studies, the unvegetated sediments sampled here were experimentally cleared plots located within the seagrass meadow. Organic matter content, a known driver of $\mathrm{N}$ fixation rates, did not differ between the bare sites and surrounding seagrass sediments (data not shown); more importantly, the sediment slurries could not capture the full effects of seagrass presence, as intact shoots were excluded from the incubations. It is therefore not surprising to find that rates were similar and low in both the seagrass and bare sediments in the slurry incubations.

In comparison, the push-pull rates were much higher than the slurry rates for both seagrass and bare sediments. There also was a clear trend of higher rates in the seagrass sediments (388 vs. 268 $\mu \mathrm{mol} \mathrm{N}_{2} \mathrm{~m}^{-2} \mathrm{~h}^{-1}$, Fig. 4), indicating the importance of plant effects under in situ conditions. The difference, however, was not statistically significant, likely due to low replication of the labor-intensive push-pull incubations and high variance associated with hotspots of bacterial activity. In our previous work at this site on denitrification and dissimilatory nitrate reduction to ammonia, we found similar variation with hotspots of higher rates that were not captured in slurry incubations (Aoki \& McGlathery 2017, 2018). With greater replication of the push-pull measurements, it is possible that a statistically significant difference would have been observed. High spatial heterogeneity in the sediments likely also contributed to the increase in the acetylene reduction rates in August 2017 compared to August 2016 (Fig. 2). Overall, the slurry incubations revealed the dominance of heterotrophic $\mathrm{N}$ fixation in the seagrass sediments, and the push-pull measurements showed the much greater magnitude of rates measured directly under in situ conditions.

The magnitude of $\mathrm{N}$ fixation in seagrass sediments has important implications for understanding coastal $\mathrm{N}$ cycling. Seagrasses thrive in low-nutrient waters, and the high rates of seagrass productivity are typically supported by remineralization of organic matter (Romero et al. 2006, McGlathery 2008). In temperate $Z$. marina meadows, $\mathrm{N}$ fixation is thought to support a relatively low percentage of the total $\mathrm{N}$ demand by seagrass (5-20\%, Welsh et al. 1996, McGlathery et al. 1998, Cole \& McGlathery 2012). However, if $\mathrm{N}$ fixation rates have been significantly underestimated through widespread use of acetylene reduction, then $\mathrm{N}$ fixation will likely meet a greater proportion of seagrass growth demand. In addition, high rates of $\mathrm{N}$ fixation will be important to balancing coastal $\mathrm{N}$ budgets. For example, recent $\mathrm{N}$ budgets for 3 shallow sub-tropical estuaries found large $\mathrm{N}$ deficits that could only be partially accounted for by inputs of oceanic $\mathrm{N}$; unmeasured $\mathrm{N}$ fixation may have supplied the missing $N$ (Eyre et al. 2016). In this study, if we take the most conservative approach that the hourly push-pull rates should be scaled by a $12 \mathrm{~h}$ day, since measurements were only made during daylight hours, the total $\mathrm{N}$ fixed just during the month of June would exceed the $\mathrm{N}$ fixation measured by the acetylene reduction slurries over the entire year. This difference suggests that additional measurements of $\mathrm{N}$ fixation using direct, in situ methods are needed in order to clarify the magnitude of $\mathrm{N}$ fixation in shallow coastal sediments.

While acetylene reduction remains an affordable and simple technique to use, the discrepancies between acetylene reduction rates and those measured with direct methods $\left({ }^{30} \mathrm{~N}_{2}, \mathrm{~N}_{2}\right.$ :Ar ratio) suggest that investigators should pursue these direct tech- 
niques. The ${ }^{30} \mathrm{~N}_{2}$ push-pull method has the advantage of being conducted in situ, so that the sediment conditions are not disturbed (an especially important consideration in sediments where seagrass is present and where flow and light availability affect root exudation and hence sediment biogeochemistry). Consequently, the ${ }^{30} \mathrm{~N}_{2}$ push-pull measurements capture the full magnitude and heterogeneity of rates under field conditions, which typically exceeds variability in the lab. Future implementation of the ${ }^{30} \mathrm{~N}_{2}$ pushpull method, along with additional measurements of $\mathrm{N}_{2}$ :Ar ratios, will give us a better understanding of the magnitude and variability of $\mathrm{N}$ fixation in these important coastal ecosystems.

Acknowledgements. We thank J. P. Megonigal for use of his gas chromatograph, M. Pace for use of his mass spectrometer, A. Peresta and M. Miller for assistance in the lab, and A. Berger and L. Edwards for assistance in the field. This work was funded by the University of Virginia and by the National Science Foundation grant DEB-1237733 to the Virginia Coast Reserve Long-Term Ecological Research project.

\section{LITERATURE CITED}

An S, Gardner WS, Kana T (2001) Simultaneous measurement of denitrification and nitrogen fixation using isotope pairing with membrane inlet mass spectrometry analysis. Appl Environ Microbiol 67:1171-1178

Aoki LR, McGlathery KJ (2017) Push-pull incubation method reveals the importance of denitrification and dissimilatory nitrate reduction to ammonium in seagrass root zone. Limnol Oceanogr Methods 15:766-781

Aoki LR, McGlathery KJ (2018) Restoration enhances denitrification and DNRA in subsurface sediments of Zostera marina seagrass meadows. Mar Ecol Prog Ser 602: 87-102

Capone DG (1988) Benthic nitrogen fixation. In: Blackburn $\mathrm{TH}$, Sorensen J (eds) Nitrogen cycling in coastal marine environments. John Wiley \& Sons, New York, NY, p 85-123

Capone DG (1993) Determination of nitrogenase activity in aquatic samples using the acetylene reduction procedure. In: Kemp PF, Sherr BF, Sherr EB, Cole JJ (eds) Handbook of methods in aquatic microbial ecology. Lewis Publishers, CRC Press, Boca Raton, FL, p 621-632

Carlson-Perret NL, Erler DV, Eyre BD (2018) Dinitrogen $\left(\mathrm{N}_{2}\right)$ fixation rates in a subtropical seagrass meadow measured with a direct ${ }^{15} \mathrm{~N}-\mathrm{N}_{2}$ tracer method. Mar Ecol Prog Ser 605:87-101

Cartaxana P, Ribeiro L, Goessling J, Cruz S, Kühl M (2016) Light and $\mathrm{O}_{2}$ microenvironments in two contrasting diatom-dominated coastal sediments. Mar Ecol Prog Ser 545:35-47

Cole LW, McGlathery KJ (2012) Nitrogen fixation in restored eelgrass meadows. Mar Ecol Prog Ser 448: 235-246

Cook PLM, Evrard V, Woodland RJ (2015) Factors control- ling nitrogen fixation in temperate seagrass beds. Mar Ecol Prog Ser 525:41-51

De Rosario-Martinez H (2015) phia: Post-hoc integration analysis. $\mathrm{R}$ package version 0.2-0. http://CRAN.R-project.org/package $=$ phia

* Eyre BD, Ferguson AJP, Webb A, Maher D, Oakes JM (2011) Denitrification, $\mathrm{N}$-fixation and nitrogen and phosphorus fluxes in different benthic habitats and their contribution to the nitrogen and phosphorus budgets of a shallow oligotrophic sub-tropical coastal system (southern Moreton Bay, Australia). Biogeochemistry 102:111-133

* Eyre BD, Maher DT, Sanders C (2016) The contribution of denitrification and burial to the nitrogen budgets of three geomorphically distinct Australian estuaries: importance of seagrass habitats. Limnol Oceanogr 61:1144-1156

Fagherazzi S, Wiberg PL (2009) Importance of wind conditions, fetch, and water levels on wave-generated shear stresses in shallow intertidal basins. J Geophys Res 114: F03022

Fox J, Weisberg $S$ (2011) An $\{R\}$ companion to applied regression, $2^{\text {nd }}$ edn. Sage, Los Angeles, CA

* Fulweiler RW, Nixon SW, Buckley BA, Granger SL (2007) Reversal of the net dinitrogen gas flux in coastal marine sediments. Nature 448:180-182

* Fulweiler RW, Heiss EM, Rogener MK, Newell SE, LeCleir GR, Kortebein SM, Wilhelm SW (2015) Examining the impact of acetylene on $\mathrm{N}$-fixation and the active sediment microbial community. Front Microbiol 6:418

KGardner WS, McCarthy MJ, An S, Sobolev D, Sell KS, Brock D (2006) Nitrogen fixation and dissimilatory nitrate reduction to ammonium (DNRA) support nitrogen dynamics in Texas estuaries. Limnol Oceanogr 51:558-568

* Hansen JW, Udy JW, Perry CJ, Dennison WC, Lomstein BA (2000) Effect of the seagrass Zostera capricorni on sediment microbial processes. Mar Ecol Prog Ser 199:83-96

* Mackin JE, Aller RC (1984) Ammonium adsorption in marine sediments. Limnol Oceanogr 29:250-257

McGlathery KJ (2008) Seagrass habitats. In: Capone DG, Bronk DA, Mulholland MR, Carpenter EJ (eds) Nitrogen in the marine environment, $2^{\text {nd }}$ edn. Elsevier, New York, NY, p 1037-1072

McGlathery K (2016) Sediment grain size in seagrass restoration plots in the Virginia coastal bays, 2010-2016. Virginia Coast Reserve Long-Term Ecological Research Project Data Publication

McGlathery K, Christian R (2017) Water quality samplingintegrated measurements for the Virginia coast, 19922017 Virginia Coast Reserve Long-Term Ecological Research Project Data Publication.

McGlathery KJ, Risgaard-Petersen N, Christensen PB (1998) Temporal and spatial variation in nitrogen fixation activity in the eelgrass Zostera marina rhizosphere. Mar Ecol Prog Ser 168:245-258

* McGlathery KJ, Reynolds LK, Cole LW, Orth RJ, Marion SR, Schwarzschild A (2012) Recovery trajectories during state change from bare sediment to eelgrass dominance. Mar Ecol Prog Ser 448:209-221

*Newell SE, McCarthy MJ, Gardner WS, Fulweiler RW (2016) Sediment nitrogen fixation: a call for re-evaluating coastal $\mathrm{N}$ budgets. Estuaries Coasts 39:1626-1638

* Nielsen LB, Finster K, Welsh DT, Donelly A, Herbert RA, De Wit R, Lomstein BA (2001) Sulphate reduction and nitrogen fixation rates associated with roots, rhizomes and sediments from Zostera noltii and Spartina maritima meadows. Environ Microbiol 3:63-71 
O'Donohue MJ, Moriarty DJW, Mac Rae IC (1991) Nitrogen fixation in sediments and the rhizosphere of the seagrass Zostera capricorni. Microb Ecol 22:53-64

Oremland RS, Taylor BF (1975) Inhibition of methanogenesis in marine sediments by acetylene and ethylene: validity of the acetylene reduction assay for anaerobic microcosms. Appl Microbiol 30:707-709

Orth RJ, McGlathery KJ (2012) Eelgrass recovery in the coastal bays of the Virginia Coast Reserve, USA. Mar Ecol Prog Ser 448:173-176

Payne WJ (1984) Influence of acetylene on microbial and enzymatic assays. J Microbiol Methods 2:117-133

Pinheiro J, Bates D, DebRoy S, Sarkar D, R Core Team (2018) Linear and nonlinear mixed effects models. R package version 3.1-137. https://CRAN.R-project.org/ package $=$ nlme

R Core Team (2018) R: a language and environment for statistical computing. R Foundation for Statistical Computing, Vienna

Romero J, Lee K, Pérez M, Mateo MA, Alcoverro T (2006) Nutrient dynamics in seagrass ecosystems. In: Larkum AWD, Orth RJ, Duarte C (eds) Seagrasses: biology, ecology, and conservation. Springer, Dordrecht, p 227-254

Editorial responsibility: Robinson Fulweiler, Boston, Massachusetts, USA
Russell DG, Warry FY, Cook PLM (2016) The balance between nitrogen fixation and denitrification on vegetated and non-vegetated intertidal sediments. Limnol Oceanogr 61:2058-2075

Seitzinger SP, Garber JH (1987) Nitrogen fixation and ${ }^{15} \mathrm{~N}_{2}$ calibration of the acetylene reduction assay in coastal marine sediments. Mar Ecol Prog Ser 37:65-73

Taylor BF (1983) Assays of microbial nitrogen transformations. In: Carpenter EJ, Capone DG (eds) Nitrogen in the marine environment. Academic Press, New York, NY, p 809-837

*Welsh DT (2000) Nitrogen fixation in seagrass meadows: regulation, plant-bacteria interactions and significance to primary productivity. Ecol Lett 3:58-71

*Welsh DT, Bourgues S, De Wit R, Herbert RA (1996) Seasonal variations in nitrogen-fixation (acetylene reduction) and sulphate-reduction rates in the rhizosphere of Zostera noltii: nitrogen fixation by sulphate-reducing bacteria. Mar Biol 125:619-628

*Yin G, Hou L, Liu M, Liu Z, Gardner WS (2014) A novel membrane inlet mass spectrometer method to measure ${ }^{15} \mathrm{NH}_{4}{ }^{+}$for isotope-enrichment experiments in aquatic ecosystems. Environ Sci Technol 48:9555-9562

Submitted: September 18, 2018; Accepted: April 5, 2019

Proofs received from author(s): May 2, 2019 